\title{
INFLUENCE OF MICRONUTRIENTS ON GROWTH, YIELD AND ECONOMY OF SAPOTA cv. KALIPATTI UNDER HDP SYSTEM
}

\author{
THIRUPATHAIAH GUVVALI ${ }^{1}$, SHIROL. A. M $^{2}$ \& SUMANGALA KOULAGI ${ }^{3}$ \\ ${ }^{I}$ Department of Fruit Science, KRCCH, Arabhavi, UHS, Bagalkot, Karnataka, India \\ ${ }^{2}$ Department of Horticulture AICRP (Fruits), KRCCH, Arabhavi, UHS, Bagalkot, Karnataka, India \\ ${ }^{3}$ Department of Plant Pathology, KRCCH, Arabhavi, India
}

The field experiment was carried out to know the response of soil and foliar application of micronutrients (i.e. Zinc, iron and boron) on growth, yield and economic of sapota CV. kalipatti under HDP system at Kittur Rani Chennamma College of Horticulture, Arabhavi during 2015-2016. Zinc and iron sulphates are used for soil and foliar application, boron for soil application sodium tetraborate (Jai bore) and for the foliar application solubor were used. The results revealed that foliar application, $0.5 \% \mathrm{ZnSO}+0.5 \% \mathrm{FeSO} 4+0.3 \% \mathrm{~B}$ shows significant increase of plant growth, i.e. plant height $(3.55 \mathrm{~m})$, spread $\left(10.42 \mathrm{~m}^{2}\right)$, tree volume $\left(5.18 \mathrm{~m}^{3}\right)$ and tertiary branches $(134)$, yield $(20.60 \mathrm{~kg}$ tree $^{-1}$ and $23.44 \mathrm{tha}^{-1}$ ) and economy i.e. maximum BCR (benefit cost ratio) 3.49 and highest additional B/C (10.55) over control.
\end{abstract}

KEY WORDS: BCR, Boron, Iron and Zinc

Received: May 04, 2017; Accepted: May 23, 2017; Published: Jun 05, 2017; Paper Id.: IJASRJUN201751

\section{INTRODUCTION}

Sapota (Manilkara achras Mill.), native of Mexico belongs to the family Sapotaceae. It is a delicious fruit mainly introduced for its fruits. Many fruit growers were attracted to the cultivation of sapota on account of its better adaptation to diverse soil and climatic conditions. It is getting popular in countries viz., India, Srilanka, Jamaica, Burma, Philippines, Central Asia and Southern Florida. It is gaining more importance in the tropical, subtropical and semiarid climate. It can also sustain wasteland and marginal lands, but fruit set, yield and the economy were inferior due to improper nutrition. This crop also suffers from a malady called mummification or stone fruit, is very severe in old orchards in certain areas of hill zones, where the rainfall exceeds $2500 \mathrm{~mm}$, annually. The severity leads to a loss of crop to the tune of more than 70 per cent (Satish, 2003).

The successful commercial cultivation of this crop depends on many factors such as climate, soil, irrigation, fertilizer, spacing and season of growing etc. Among the different management practices, nutrient management plays an important role in growth, yield and economy fruits under high density planting (HDP) system. To perform sustainable yield and economy, it needs high amount of nutrients (Mishra, 2014). The intensive and exploitative agriculture with high inputs and high yielding varieties and improved technologies, have helped for better fruit production. But, under high density planting competition for water and nutrients and the major nutrients usually supplied through straight fertilizers or mixture in an aggressive manner, it leads to the depletion of micronutrients by maximum utilization, it will ultimately result in loss of yield and economy. To sustain the yield and economy of fruit crops, maintenance of micro and secondary nutrients becomes very pertinent 
to foresee the emerging nutrient deficiencies and to evolve suitable ameliorating technologies.

Present days, the major nutrients are usually supplied through straight fertilizers or mixed fertilizers to enhance the yield of sapota and it will results in depletion of micronutrients. Sapota has the problem of low fruit setting and shedding of fruits. Only about 10-12 per cent of the total fruits set, and retains until maturity. Most of the fruit-drop occurs immediately after fruit set. Increase in fruit set and retention are possible by spraying of boron (B), Iron ( $\mathrm{Fe})$ that promotes the formation of chlorophyll pigments, acts as an oxygen carrier and reactions involving cell division and growth. Zinc (Zn) aids in regulating plant growth hormones and enzyme system, necessary for chlorophyll production, carbohydrate and starch formation. Zinc is important for the formation and activity of chlorophyll, and in the functioning of several enzymes and the growth hormone, auxin (Jeyakumar and Balamohan, 2013).

Micronutrients play a major role in crop production due to their essentiality in plant metabolism and adverse effects that manifest due to their deficiency. Besides affecting plant growth, micronutrients also play a major role in disease resistance in cultivated crop species. Micronutrients can tremendously boost the crop yield and improve economy and post-harvest life of horticultural produce (Raja, 2009). The foliar application of macro and micronutrients has a very important role in improving fruit set, productivity and economy of fruits. It has also a beneficial role in recovery of nutritional and physiological disorders in fruit trees. Various experiments have been conducted earlier on a foliar spray of micro-nutrients in different fruit crops and shown significantly improved yield and economics of fruits (Kumar and Verma, 2004).

Therefore, based on the possible benefits of micronutrients, the present study was carried out to know the effect of soil and foliar application of micronutrients on growth, yield and economics of support under high-density planting.

\section{MATERIALS AND METHODS}

Field experiments were conducted at Kittur Rani Chennamma College of Horticulture, Arabhavi, Belagavi District during 2015-2016. Experiments were laid out in Randomized Complete Block Design with eleven treatments viz., T1: control- [only recommended dose of fertilizers RDF], T2: water foliar application + RDF, T3: ZnSO4 (50 g/plant soil application)+RDF, T4: FeSO4 (40 g/plant soil application)+RDF, T5: Boron (Jai bore $25 \mathrm{~g} / \mathrm{plant}$ soil application)+RDF, T6: ZnSO4 (foliar application 0.5 per cent)+RDF, T7: FeSO4 (foliar application 0.5 per cent)+RDF, T8: boron (Solubor for foliar application 0.3 per cent)+RDF, T9: ZnSO4 $(50 \mathrm{~g})+$ FeSO4 $(40 \mathrm{~g})+$ boron $(25 \mathrm{~g})$ for soil application+ RDF. T10: ZnSO4 $(0.5 \%)+$ FeSO4 $(0.5 \%)+$ boron $(0.3 \%)$ for foliar application+ RDF. Micronutrients (foliar application) and T11: $\mathrm{T} 9+\mathrm{T} 10+\mathrm{RDF}$. These nutrients are applied in two times as foliar i.e. 1st at 50 per cent flowering and another at fruits at pea size. For soil application, micronutrients applied along with RDF. For post harvest studies, the fruits were stored at room temperature i.e. day and night temperature is $\left(25 \pm 2{ }^{\circ} \mathrm{C}\right.$ and $18 \pm 2{ }^{\circ} \mathrm{C}$ respectively), \& $\mathrm{RH}(70 \pm 5 \%)$. The tree volume was calculated with the following formula.

Tree volume $=\left(\frac{\mathrm{NS} \times \mathrm{EW}}{2}\right)^{2}$ Canopy height $(\mathrm{m}) \times \mathrm{CF}$

Where,

NS- Plant spread in north to south (m)

EW- Plant spread in east to west (m) 
CF- Correction factor -0.445 .

\section{STATISTICAL ANALYSIS OF EXPERIMENTAL DATA}

The experimental data collected relating to different parameters were statistically analyzed as described by Sundar et al. (1972), and the results were tested at 5 per cent level of significance by Fischer method of analysis of variance.

\section{RESULTS AND DISCUSSIONS}

\section{The Effect of Micronutrients on Plant Height and Spread}

In present, the soil application and foliar spray of micronutrients significantly influenced the plant height and spread sapota cv. Kalipatti under HDP system (Table 1). The application of $100 \%$ recommended dose of fertilizers along with foliar application of ZnSO4 $(0.5 \%)+\mathrm{FeSO} 4(0.5 \%)+\mathrm{B}(0.3 \%)$ per tree (T10) and foliar spray of 0.5 per cent ZnSO4 per tree (T6) was shown highest plant height $(3.55 \mathrm{~m})$, and minimum plant height $(2.80 \mathrm{~m})$ was recorded in T1 (control). The increase in plant height in the present investigation might be due to the foliar application of micronutrients increase the photosynthetic compounds inside the plant tissue, which may be involved in the synthesis of tryptophan, which is a precursor of IAA, so ultimately increases the vegetative growth of the plant and, the similar result was found by Ram and Bose, 2000). The highest plant spread was noticed in T10 (10.46 m2) and the lowest $(6.03 \mathrm{~m} 2)$ was noticed in T3, which is because of sufficient amount of zinc in the plant improve the harmful effects of boron (B) leads to a deficiency. Similar results were observed by Sayed et al. (2012); Jagtap et al. (2013) and Deshmukh et al. (2015) in acid lime. Also, the similar findings were given by Bhalerao and Patel (2015) in papaya; Saraswathy et al. (2004) in sapota; Ahmad et al. (2012) in Feutrelle's early (Citrus reticulata Blanco); Jagtap et al. (2013) in acid lime; Deshmukh et al. (2015) in acid lime; Gurjar et al. (2015) in Kinnow mandarin and Lakshmipathi et al. (2015) in cashew.

\section{The Effect of Micronutrients on Stem Girth, Tree Volume and Number of Tertiary Branches}

The present study indicates that the maximum stem girth has recorded in T10 $(7.62 \mathrm{~cm})$ minimum stem girth was recorded in T11 $(5.20 \mathrm{~cm}$ ) (Table 1). An increase in the stem girth was also due to application of the proper dose of micronutrients, because they have important functioning, role in chlorophyll synthesis and development of cells in meristemetic tissues, similar findings by Shekar et al. (2010), Bhalerao and Patel (2015) in papaya; Rashid and Mondal (2007) and Ghanta and Mitra (1995) in banana.

Maximum tree volume was recorded in T8 $(5.18 \mathrm{~m} 3)$ and the lowest recorded in T11 (3.32 m3). This is may be due to active translocation of carbohydrates, which helps in healthy terminal bud growth in the presence of boron and the same results was recorded by Deshmukh et al. (2015) in acid lime. The treatment T8 and T10 recorded the maximum number of tertiary branches (136 and 134). Whereas, the minimum number of tertiary branches (31) has recorded in T11. The increase in the number of tertiary branches might be due to combination of zinc, iron and boron facilitates the transport of carbohydrates through cell membrane, i.e. starch and sugars as well as plays an important role in the activator for many enzymes which promote the growth of the plant. A similar trend was also reported by Sayed et al. (2012) and Malik et al. (2011) in Amaranthus. 
Table 1: Effect of Micronutrients on Plant Height of Sapota (Recorded at Quarterly)

\begin{tabular}{|c|c|c|c|c|c|}
\hline Treatments & $\begin{array}{c}\text { Plant } \\
\text { Height } \\
\text { (m) }\end{array}$ & $\begin{array}{c}\text { Plant } \\
\text { Spread } \\
\left(\mathbf{m}^{2}\right)\end{array}$ & $\begin{array}{l}\text { Stem Girth } \\
\qquad(\mathrm{cm})\end{array}$ & $\begin{array}{l}\text { Tree Volume } \\
\qquad\left(\mathbf{m}^{3}\right)\end{array}$ & $\begin{array}{c}\text { Number of } \\
\text { Branches per } \\
\text { Plant }\end{array}$ \\
\hline T1- Control (RDF) & 2.80 & 6.93 & 5.50 & 3.30 & 32 \\
\hline T2- RDF + Water spray & 2.96 & 7.13 & 5.51 & 3.41 & 33 \\
\hline T3- RDF + 50 g ZnSO4 per tree (SA) & 2.97 & 6.03 & 5.87 & 3.18 & 59 \\
\hline T4- RDF + 40 g FeSO4 per tree (SA) & 3.48 & 10.17 & 7.57 & 4.97 & 116 \\
\hline T5- RDF + 25 g B per tree (SA) & 3.49 & 9.18 & 7.07 & 4.89 & 90 \\
\hline T6- RDF + $0.5 \% \mathrm{ZnSO} 4$ per tree $(\mathrm{FA})$ & 3.55 & 9.70 & 6.77 & 4.93 & 55 \\
\hline $\mathrm{T} 7-\mathrm{RDF}+0.5 \% \mathrm{FeSO} 4$ per tree $(\mathrm{FA})$ & 3.35 & 9.50 & 7.05 & 4.37 & 83 \\
\hline $\mathrm{T} 8-\mathrm{RDF}+0.3 \% \mathrm{~B}$ per tree $(\mathrm{FA})$ & 3.40 & 10.50 & 7.45 & 5.18 & 136 \\
\hline $\begin{array}{l}\text { T9- RDF +50 g ZnSO4+40 g FeSO4+ } \\
25 \text { g B per tree (SA) }\end{array}$ & 3.08 & 10.25 & 6.30 & 4.31 & 78 \\
\hline $\begin{array}{l}\mathrm{T} 10-\mathrm{RDF}+0.5 \% \mathrm{ZnSO} 4+0.5 \% \\
\text { FeSO } 4+0.3 \% \text { B per tree }(\mathrm{FA})\end{array}$ & 3.55 & 10.45 & 7.62 & 4.56 & 134 \\
\hline T11- T9+ T10. & 2.82 & 6.77 & 5.20 & 3.32 & 31 \\
\hline S. Em \pm & 0.05 & 0.19 & $\mathbf{0 . 1 0}$ & 0.10 & 6.92 \\
\hline C.D. at 5\% & 0.15 & 0.56 & 0.29 & 0.29 & 20.36 \\
\hline
\end{tabular}

\section{The Effect of Micronutrients on Yield Attributes of Sapota}

A significant difference was observed in the yield per tree with application of soil and foliar application of micronutrients on sapota (Table 2). The maximum number of fruits (189.50) was recorded in the treatment T10 (foliar spray of $0 \mathrm{ZnSO} 4(0.5 \%)+\mathrm{FeSO} 4(0.5 \%)+\mathrm{B}(0.3 \%)$ per tree.) and in the T6 (155.00) and the minimum number fruits harvested in T11 (41.00). The increased number of fruits due to increased fruit set and fruit retention, it was attributed by application of combined form and reduced number of fruit in T11; it may be higher dose of i.e. one time soil and two times failure become in excess results in an adverse effect on other nutrients. A significant difference was observed in the yield per tree and yield $\left(\mathrm{kg} \mathrm{ha}^{-1}\right)$ with application of soil and foliar application of micronutrients on sapota. The maximum yield (20.60 kg tree $\mathrm{e}^{-1}$ and $23.44 \mathrm{t} \mathrm{ha}^{-1}$ ) was recorded in T10 followed by T4, (14.58 kg tree ${ }^{-1}$ and $16.2 . \mathrm{t}$ ha $\left.{ }^{-1}\right)$ which was statistically on par with T8 $\left(14.33 \mathrm{~kg}_{\text {tree }}^{-1}\right.$ and $\left.15.83 \mathrm{tha}^{-1}\right)$. However, the low yield per tree $\left(3.35 \mathrm{~kg} \mathrm{tree}^{-1}\right.$ and $\left.3.72 \mathrm{t} \mathrm{ha}^{-1}\right)$ was recorded in treatment $\mathrm{T} 11$. The increased number of fruits due to increased fruit set and fruit retention, it was attributed by application of combined form and reduced number of fruit in T11; it may be higher dose of i.e. one time soil and two times failure become in excess results in an adverse effect on other nutrients.

The increased number of fruits and yield might be an additional dose of nutrient supplied through micronutrients utilized more for cell elongation, cell division, RNA, DNA synthesis and the plants only four years old it means these plants are in active growing stage it will also one of reason for good response to micronutrient application. The similar results were reported by Pathak et al. (2010), these findings in accordance to Mohsen (2015) in the grape; Aisha et al. (2015) in Kinnow and Tulsi et al. (2015) in mango. The increase in the fruit retention by application of micronutrient has also been reported in fruits like Guava (Gaur et al., 2014) and peach (Yadav et al., 2013).

Table 2: Effect of Micronutrients on Fruit Yield of Sapota

\begin{tabular}{|c|c|c|c|}
\hline Treatments & $\begin{array}{c}\text { No. of Fruits } \\
\text { Per Tree. }\end{array}$ & $\begin{array}{c}\text { Yield kg } \\
\text { Tree }^{-1} \\
\end{array}$ & Yield $\left(\mathrm{t} \mathrm{ha}^{-1}\right)$ \\
\hline T1- Control (RDF) & 48.67 & 4.32 & 4.80 \\
\hline T2- RDF + Water spray & 59.00 & 4.79 & 5.32 \\
\hline T3- RDF + 50 g ZnSO4 per tree (SA) & 75.33 & 6.07 & 6.74 \\
\hline T4- RDF + 40 g FeSO4 per tree (SA) & 143.67 & 14.58 & 16.20 \\
\hline
\end{tabular}




\begin{tabular}{|l|c|c|c|}
\hline T5- RDF + 25 g B per tree (SA) & 112.67 & 12.32 & 13.69 \\
\hline T6- RDF + 0.5\% ZnSO4 per tree (FA) & 155.00 & 9.30 & 10.33 \\
\hline T7- RDF + 0.5\% FeSO4 per tree (FA) & 120.50 & 10.83 & 11.98 \\
\hline T8- RDF + 0.3\% B per tree (FA) & 142.50 & 14.33 & 15.83 \\
\hline T9- RDF + 50 g ZnSO4+40 g FeSO4+ 25 g B per tree (SA) & 77.50 & 6.86 & 7.58 \\
\hline $\begin{array}{l}\text { T10- RDF + 0.5\% ZnSO4 + 0.5\% FeSO4 + 0.3\% B per tree } \\
\text { (FA) }\end{array}$ & 189.50 & 20.60 & 23.44 \\
\hline T11- T9+ T10 & 41.00 & 3.35 & 3.72 \\
\hline S. Em \pm & $\mathbf{2 . 6 0}$ & $\mathbf{0 . 2 7}$ & $\mathbf{0 . 3 0}$ \\
\hline C. D. at 5\% & $\mathbf{7 . 6 8}$ & $\mathbf{0 . 7 8}$ & $\mathbf{0 . 8 7}$ \\
\hline
\end{tabular}

\section{The Effect of Micronutrients on Cost Benefit Ratio of Sapota}

The cost of cultivation per hectare (Rs. $48,592.93$ - 68, 174.92) revealed that, the treatment T10 gave the maximum gross income (Rs. 2, 28, 866.00), followed by treatment T4 (Rs. 1, 61, 983.20). The maximum net returns was obtained in treatment T10 (Rs. 1, 63, 425.10) followed by T4 (Rs. 98, 141.88) and the highest benefit to cost (B: C) ratio was observed in treatment T10 (3.49) where the treatment was supplied with foliar spray of $0.5 \% \mathrm{ZnSO} 4+0.5 \% \mathrm{FeSO} 4+$ $0.3 \%$ B per tree followed by T4 (2.53) and the negative B: C (-0.64) was obtained in T11 this is because the nutrients were found to toxic levels in leaf nutrient status (Table 3 and Figure 1). The toxic level of micronutrients might be the cause of low yield and high input requirements found to be the cause of negative B: C ratio. Regarding the additional benefit cost ratio (Table 4) the highest (10.55) was obtained in T10 followed by T4 (7.27) and in T8 (6.56).

Table 3: Effect of Micronutrients on Cost Benefit Ratio of Sapota

\begin{tabular}{|l|c|c|c|c|}
\hline \multicolumn{1}{|c|}{ Treatments } & $\begin{array}{c}\text { Total cost } \\
(\text { Rs. })\end{array}$ & $\begin{array}{c}\text { Gross } \\
\text { Returns } \\
(\text { Rs. })\end{array}$ & $\begin{array}{c}\text { Net Returns } \\
(\text { Rs. })\end{array}$ & B/C \\
\hline T1- Control (RDF) & 48593.92 & 51106.00 & 2512.08 & 1.05 \\
\hline T2- RDF + Water spray & 49969.92 & 53216.90 & 3246.98 & 1.06 \\
\hline T3- RDF + 50 g ZnSO4 per tree (SA) & 59383.92 & 67437.70 & 8053.78 & 1.13 \\
\hline T4- RDF+ 40 g FeSO4 per tree (SA) & 63841.92 & 161983.80 & 98141.88 & 2.53 \\
\hline T5- RDF + 25 g B per tree (SA) & 64152.92 & 136875.20 & 72722.28 & 2.13 \\
\hline T6- RDF + 0.5\% ZnSO4 per tree (FA) & 64007.92 & 103323.00 & 39315.08 & 1.61 \\
\hline T7- RDF + 0.5\% FeSO4 per tree (FA) & 63829.92 & 120321.30 & 56491.38 & 1.88 \\
\hline T8- RDF + 0.3\% B per tree (FA) & 65062.92 & 159206.30 & 94143.38 & 2.44 \\
\hline T9- RDF + 50 g ZnSO4+40 g FeSO4+ 25 g B per tree (SA) & 61294.92 & 76214.60 & 14919.68 & 1.24 \\
\hline $\begin{array}{l}\text { T10- RDF + 0.5\% ZnSO4 + 0.5\% FeSO4 + 0.3\% B per tree } \\
\text { (FA) }\end{array}$ & 65440.92 & 228866.00 & 163425.10 & 3.49 \\
\hline T11- T9+ T10 & 57501.92 & 37218.50 & -20283.40 & -0.64 \\
\hline
\end{tabular}




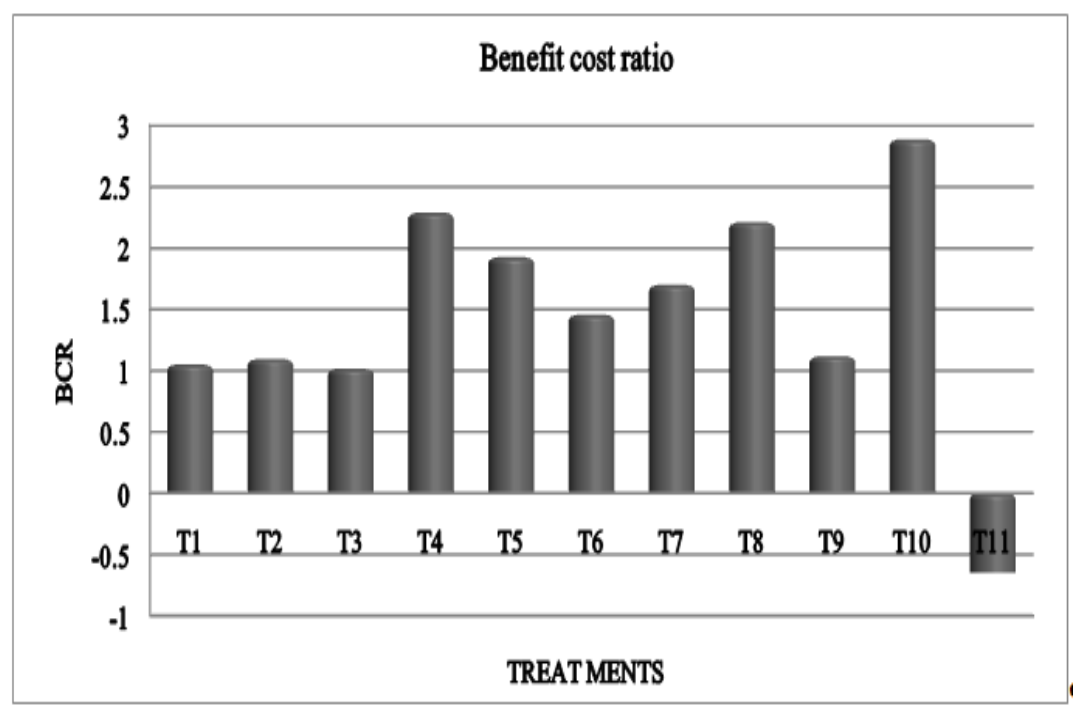

Figure 1: Effect of Micronutrients on Cost Benefit Ratio of Sapota

Table 4: Effect of Micronutrients on Additional Cost Benefit Ratio of Sapota

\begin{tabular}{|c|c|c|c|c|}
\hline Treatment & $\begin{array}{c}\text { Additional } \\
\text { Cost (Rs.) }\end{array}$ & $\begin{array}{c}\text { Additional } \\
\text { Gross Returns } \\
\text { (Rs.) }\end{array}$ & $\begin{array}{l}\text { Additional Net } \\
\text { Returns (Rs.) }\end{array}$ & $\begin{array}{c}\text { Additional } \\
\text { B/C }\end{array}$ \\
\hline T1- Control (RDF) & 0 & 0 & 0 & 0 \\
\hline T2- RDF + Water spray & 1376 & 2110.9 & 734.9 & 1.53 \\
\hline T3- RDF + 50 g ZnSO4 per tree (SA) & 10790 & 16331.7 & 5541.7 & 1.51 \\
\hline T4- RDF + 40 g FeSO4 per tree (SA) & 15248 & 110877.8 & 95629.8 & 7.27 \\
\hline T5- RDF + 25 g B per tree (SA) & 15559 & 85769.2 & 70210.2 & 5.51 \\
\hline T6- RDF + $0.5 \% \mathrm{ZnSO} 4$ per tree (FA) & 15414 & 52217 & 36803 & 3.38 \\
\hline T7- RDF + 0.5\% FeSO4 per tree (FA) & 15236 & 69215.3 & 53979.3 & 4.59 \\
\hline T8- RDF + 0.3\% B per tree (FA) & 16469 & 108100.3 & 91631.3 & 6.55 \\
\hline $\begin{array}{l}\text { T9- RDF + } 50 \text { g ZnSO4+40 g FeSO4+ } 25 \mathrm{~g} \mathrm{~B} \\
\text { per tree (SA) }\end{array}$ & 12701 & 25108.6 & 12407.6 & 1.99 \\
\hline $\begin{array}{l}\mathrm{T} 10-\mathrm{RDF}+0.5 \% \mathrm{ZnSO} 4+0.5 \% \mathrm{FeSO} 4+ \\
0.3 \% \mathrm{~B} \text { per tree }(\mathrm{FA})\end{array}$ & 16847 & 177760 & 160913 & 10.55 \\
\hline $\mathrm{T} 11-\mathrm{T} 9+\mathrm{T} 10$ & 8908 & -13887.5 & -22795.5 & -1.59 \\
\hline
\end{tabular}

\section{CONCLUSSIONS}

From this study, it can be concluded that $\mathrm{T} 10-\mathrm{RDF}+0.5 \% \mathrm{ZnSO} 4+0.5 \% \mathrm{FeSO} 4+0.3 \% \mathrm{~B}$ per tree foliar application can be recommended for increased growth (height, spread and tree volume), yield and economy of sapota cv. Kalipatti is under high density planting system for fruits without any adverse effect on the environment, and also it will promote increased productivity by the timely availability of required nutrients.

\section{ACKNOWLEDGEMENT}

The authors are highly knowledge in Research Services, Mr. A. M. Shirol, Chairman of my Advisory Committee, Assoc. Prof of Horticulture, AICRP (Fruits) K.R.C.C.H, Arabhavi, for his exemplary guidance, valuable feedback, and constant encouragement throughout the duration of the research, his valuable suggestions were of immense help throughout my research work and Dr. Nagesh Naik member of my Advisory Committee, Professor and Head Dept. of Fruit Science. K.R.C.C.H, Arabhavi, whose generous, splendid and precious guidance till the last minute helped me in completing this task with edifying counsel, constructive suggestions, necessary guidance and advice, was able to complete 
my investigation successfully.

\section{REFERENCES}

1. Aisha, I., Muhammad, Y. A., Mumtaz, H., Muhammad, A., Rashid, A. and Ali, K., 2015, Effect of micronutrients (Zn, Cu and B) on photosynthetic and fruit yield attributes of Citrus reticulata blanco var. Kinnow. Pak. J. Bot., 47(4): 1241-1247.

2. Ahmad, S. K., Waseem, U., Aman, U. M., Rashid, A., Basharat, A. S. and Ishtiaq, A. R., 2012, Exogenous applications of boron and zinc influence leaf nutrient status, tree growth and fruit quality of feutrell"s early (Citrus reticulata blanco). Pak. J. Agri. Sci., 49(2): 113-119.

3. Bhalerao, P. P. and Patel, B. N., 2015, Effect of foliar application of Ca, Zn, Fe and B on growth, yield and quality of papaya var. Taiwan red lady. Indian J. Hort., 72(3) : 325- 328.

4. Deshmukh H. K., Nimbolkar P. K., Paithankar D. H. and Dewangan R. K., 2015, Effect of plant growth regulators and micronutrients on growth and yield

5. of acid lime (Citrus aurantifolia swingle) in hasta bahar. Int. J. Agri. Env. Biotech., 8(3): 615-620

6. Gaur, B., Beer, K., Hada, T.S., Kanth, N. and Syamal, M. M., 2014, Studies on the effect of foliar application of nutrients and GA3 on fruit yield and quality of winter season guava. The Ecoscan, 6: 479-483.

7. Ghanta, P. K. and Mitra, S. K., 1995, Effect of micronutrients on growth, flowering, leaf nutrient content and yield of banana cv. Giant Governer. Crop Res. (Hisar), 6(2): 284-287.

8. Gurjar, M. K., Kaushik. R. A. and Prerna, B., 2015, Effect of Zinc and Boron on the Growth and Yield of Kinnow Mandarin. Int. J. Sci. R., 4 (4):2277 - 8179.

9. Jagtap,V. M., Patel, H. C. and Nehete, D. S., 2013, Effect of foliar application of plant growth regulators and micronutrients on growth and yield of acid lime cv. kagzi (Citrus aurantifolia, Swingle). J. Life Sci., 10(2): 469 - 472.

10. Jeyakumar, P. and Balamohan, T. N., 2013, Micronutrients for horticultural crops. (http://agritech.tnau.ac.in).

11. Kumar, S. and Verma, D. K., 2004, Effect of micro-nutrients and NAA on yield and quality of litchi cv. Dehradun. Proceedings of International Sem. on Recent Trend in Hi-tech Horticulture and Post Harvest Tech., pp.193.

12. Lakshmipathi, Dinakara, A. J., Kalaivanan, D., Mohana, G. S. And Meena, R. K., 2015, Effect of foliar application of micronutrients on reproductive growth of cashew (Anacardium occidentale L.) under south west coast region of Karnataka, India. Trends in Biosciences., 8 (2): 447-449.

13. Malik, N. J., Chamon, A. S., Mondal, M. D., Elahi, S. F. and Faiz, S. M. A., 2011, Effect of different levels of zinc on growth and yield of red amaranthus and rice. J. Bangladesh young Res., 1(1):79-91.

14. Mishra, D., 2014, Nutrient removal studies in guava under high density orcharding system. J. Agri. Crop Sci., 1: 36-38

15. Mohsen, 2015, Minimizing shot berries level and improving quality of superior seedless table grapes using boron and GA3. Int. J. Curr. Res. Biosci. Pl. Biol., 2(6): 107-114.

16. Pathak, P. K. and Mitra, S. K., 2008, Effect of phosphorus, potassium, sulphur and boron on litchi. Indian J. Hort., 65(2): 137140.

17. Raja, E. M., 2009, Importance of micronutrients in the changing horticultural scenario. J. Hort. Sci., 4 (1): 1-27.

18. Ram, R. A. and Bose, T. K., 2000, Effect of foliar application of mangnesium and micronutrients on growth, yield and fruit quality of mandarin orange. Indian J. Hort., 57(3): 215-220. 
19. Rashid, M. H. A. and Mondal, M. F., 2007, Effects of micronutrients on the growth, yield ans quality of banana. J. Bangladesh Soc. Agri. Sci. Technol., 4(3\&4): 17-20.

20. Saraswathy, S., Balakrishnan, K., Anbu, S., Azhakia M, R. S. and Thangaraj, T., 2004, Effect of zinc and boron on growth, yield and quality of sapota (Manilkara achras Mill.) cv. PKM-1. South Indian Hort., 52(1-6): 41- 44.

21. Satish, K. B., 2003, Nutrient status of mummified and non mummified sapota cv. Kalipatti. M.Sc. (Hort.) Thesis, University of Agricultural Sciences, Bangalore, pp.1-3.

22. Sayed, R. M., Mohammad, G. and Maryam, R., 2012, The interaction of zinc with other elements in plants:a review Int. J. Agri. Crop Sci., 4 (24): 1881-1884.

23. Shekar, C., Yadav, A. L., Singh, H. K. and Singh, M. K., 2010, Influence of micronutrients on plant growth, yield and quality of papaya fruit (Carica papaya L.) cv. Washington. Asian J. Hort., 5(2): 326-329.

24. Sundar R. N., Nagaraj, S., Venkataramu, M. N. and Jagannath, M. K., 1972, Design and analysis of field experiments, Univ. Agric. Sci., pp. 106-110.

25. Yadav, V., Singh, P. N. and Yadav, P., 2013, Effect of foliar fertilization of boron, zinc and iron on fruit growth and yield of low-chill peach cv. Sharbati. Int. J. Scient. Res. Publ,. 3(8): 1-6. 